\title{
Nanoparticle Self-assembly at Liquid-liquid Interface
}

\author{
Akash Mishra ${ }^{1}$, Sunita Srivastava ${ }^{2, *}$ \\ ${ }^{1}$ Centre for Research in Nanotechnology and Science, IIT Bombay, Powai, Mumbai, India \\ 2 Department of Physics, IIT Bombay, Powai, Mumbai, India
}

(Received 10 January 2021; revised manuscript received 25 March 2021; published online 09 April 2021)

\begin{abstract}
We present our experimental results based on the interfacial assembly of the nanoparticle biomolecule membrane hybrid at the liquid-liquid interface. The adsorption dynamics of positively charged lipid 1,2 dimyristoyl-3-trimethylammonium-propane (DMTAP), at the water-chloroform (W/Chl) interface is investigated via the in-situ measurement of the interfacial surface tension using the Langmuir Blodgett technique. The result based on measurements of the surface tension for various concentrations of the DMTAP lipid molecules reveals that the absorption of molecules at the W/Chl increases with an increase in DMTAP concentration. The citrate coated negatively charged gold nanoparticle (Au NPs) assembly at the positively charge lipid membrane were achieved via electrostatic attraction between the Au NPs and lipid biomembrane. The surface morphology of the 2D lipid membrane and the Au NPs/lipid complex were characterized ex-situ using atomic force microscopy (AFM) by transferring the Au NPs/lipid complex at the interface, on to the solid substrate using the Langmuir-Blodgett (LB) technique. The ex-situ AFM and the insitu surface tension data indicate that the adsorption of the lipid molecules improves with an increase in concentration. The AFM data reveals the formation of high-density Au NP film at the interface.
\end{abstract}

Keywords: Langmuir-Blodgett technique, Lipid monolayer, Atomic force microscopy, DMTAP, Liquidliquid interface, UV-Vis spectroscopy, Zeta potential.

DOI: $10.21272 /$ jnep.13(2).02016

PACS numbers: $87.64 \mathrm{Dz}, 52.70 . \mathrm{Kz}$

\section{INTRODUCTION}

Biomolecule-nanoparticle assembly at the liquid-liquid interface has attracted enormous interest between researchers due to its application in biological systems, such as modeling biological membranes, development of biosensors, integrated chips, etc. [1-4]. Amphiphilic molecules form different supramolecular structures at the interface due to self-assembly. Self-assembly in this context depends on the energy dissipation by movement and orientation of biomolecules due to Brownian motion which should be comparable to thermal energy. Here due to thermal energy, weak non-covalent bonds between molecules continuously break and recombine to reach equilibrium position where activation energy is minimum. This equilibrium position is very sensitive to change in condition due to very weak interaction between molecules. This helps in forming different structures by controlling the shape, size, local environment, and aggregation state of biomolecules [1,2].

Numerous works have been done using the LB technique at the air/water interface to understand the adsorption dynamics of lipid molecules to form the monolayer [3-5]. In case of charged lipid molecules, the structure of the lipid membrane depends on the lipid composition, due to electrostatic repulsion between positively charged molecules [6]. The lipid membrane at the interface provides an ideal model system to study the structural as changes due to its interaction with biomolecules as well as nanoparticles. It has been found that the DNA macromolecules interact electrostatically with cationic lipid and do not penetrate into the hydrophobic tail [7] of the lipid membrane. Effect of alkyl coated gold nanoparticle organization (Au NPs) has also been studied on different compositions of lipid membrane at air-water interface and it has been found that the configuration of Au NPs changes with changing the composition of lipids in the mixture and it depends on thermodynamic properties of the mixed lipids [8]. Charged lipid membrane at the interface can be a guiding force for the assembly of oppositely charged nanoparticle at the interface due to electrostatic attraction. Such assembly processes not only allow creating ordered structure in perfectly confined structure but also allows tuning the surface morphology by changing the nanoparticle-membrane interaction at the nanoscale $[9,10]$. These system offers as a model system to study the physics of assembly for confined as well investigate the nanoparticle - biomolecule interaction.

In the present work, we have focused our investigation on the adsorption dynamics of positively charged lipid molecules (DMTAP) at the W/Chl interface. Further, we have studied the in-situ self-assembly of $\mathrm{Au}$ NPs at the liquid-liquid interface using the LB technique. The ex-situ surface morphology of the lipid biomembrane and lipid-nanoparticle assembly reveals the formation of high-density monolayer at the interface.

\section{MATERIALS AND METHODS}

\subsection{Materials}

Positively charged lipid 1, 2-dimyristoyl-3-trimethyleammoniumpropane (DMTAP) and Chloroform (HPLC grade) were purchased from Avanti polar and sigmaAldrich respectively. Gold colloid of $10 \mathrm{~nm}$ size was purchased from TedPella and used as it is. Ultrapure DI water of 18.2 $\mathrm{M} \Omega$ was used in all experiments.

\footnotetext{
*sunita.srivastava@iitb.ac.in

The results were presented at the International Conference on Multifunctional Nanomaterials (ICMN2020)
} 


\subsection{Lipid Monolayer Formation}

A stock solution of DMTAP of $0.17 \mathrm{mM}$ concentration was prepared in chloroform using an appropriate quantity of lipid and solvent. Adequate volumes of the stock solution were diluted to $1.7 \mu \mathrm{M}$ solution. This solution is treated as a master solution for preparing different concentration of lipid assembly. Solution in chloroform was first added to the glass beaker followed by sonication for $5 \mathrm{~s}$ and then incubated for $15 \mathrm{~min}$ for equilibrium. Equal volume of DI water is added gently to form the W/Chl interface. The same protocols were used for preparation of samples of different lipid compositions.

\subsection{Monolayer Transfer}

For the ex-situ surface morphology characterization, the lipid membranes were transferred on to a silicon substrate using the vertical dipping LB method. Charged solid substrates prepared using layer-by-layer assembly of charged polymers using the method described in [11] were used for lipid membrane transfer. The films were transferred at the downward and upward speed of $2 \mathrm{~mm} / \mathrm{min}$ and $5 \mathrm{~mm} / \mathrm{min}$, respectively. Downward speed is kept low to remove mechanical vibrations.

The NanoScope IV of digital instruments by Veeco Metrology Group was used for the surface morphology characterization. The surface imaging were done using AFM instrument operated in tapping mode at a scan rate of $1 \mathrm{kHz}$ at 256 lines per scan for all samples.

\section{CHARACTERIZATIONS}

\subsection{Langmuir-Blodgett (LB) Technique and AFM}

Langmuir-Blodgett (LB) set up from Biolin instruments was used for the formation of the lipid and Au NP lipid complex at the W/Chl interface. A Platinum Wilhelmy plate of $18 \mathrm{~mm}(w), 8 \mathrm{~mm}(h)$, and $0.16 \mathrm{~mm}$ (thickness) was used to measure the surface pressure. The surface pressure can be calculated by measuring the surface tension $(\gamma)$ at the interface given by the equation:

$$
\Pi=\gamma_{l-l}-\gamma,
$$

where $\Pi$ is the surface pressure, $\gamma_{l-l}$ is the interfacial tension between both liquids and $\gamma$ is the interfacial tension due to monolayer at the interface. From the equation, it is evident that surface pressure decreases with an increase in lipid adsorption at the interface [12].
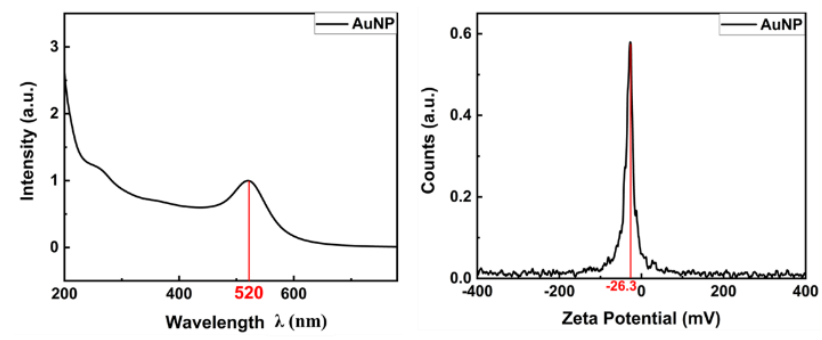

Fig. 1 - UV-Vis and zeta potential data for citrate coated Au NPs. (a) The well-defined surface plasmon peak at $520 \mathrm{~nm}$ confirms the presence of monodisperse nanoparticles of a size of $\sim 10 \mathrm{~nm}$. The peak at $\sim-26 \mathrm{mV}$ reveals the negative charge on the Au NP surface

\subsection{Characterization of Au NPs for Assembly}

Negatively charged citrate coated gold nanoparticles $\left(\mathrm{Au}-\mathrm{COO}^{-}\right)$were used for our studies. The opposite charge on the nanoparticle surface facilitates the adsorption of the particle on the positively charged DMTAP lipid membrane at the interface. The size/concentration and surface charge of the gold nanoparticle were measured using the UV-Vis spectroscopy and zeta potential measurements respectively as shown in Fig. 1. The well-defined surface plasmon peak at $520 \mathrm{~nm}$ indicates monodisperse $\mathrm{Au}$ NPs in water solvent. The concentration of nanoparticle in the base fluid is calculated using Beer-Lambert law and was found to be $\sim 2.4 \mathrm{nM}$. The negative value of $\sim-26 \mathrm{mV}$ in zeta potential graph shows that citrate coated gold colloid is negatively charged and thus can be used for electrostatically driven assembly of Au NPs at the charged lipid membrane.

\section{RESULTS AND DISCUSSION}

The surface pressure data shown in Fig. 2, at different concentrations of the lipid molecules in the chloroform sub-phase reveals the adsorption behavior of the lipid at the W/Chl interface. The surface pressure of the bare air-water and bare $\mathrm{W} / \mathrm{Chl}$ interface were measured to be $72 \mathrm{mN} / \mathrm{m}$ and $27 \mathrm{mN} / \mathrm{m}$, respectively.
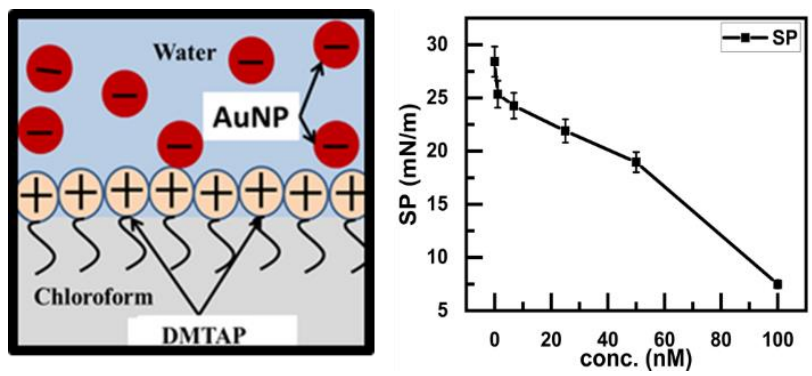

Fig. 2 - (a) Schematic of charged lipid membrane (DMTAP) at the W/Chl interface. The oppositely charged Au NPs adsorb at the headgroup of the lipid membrane via electrostatic interactions. (b) Surface pressure vs concentration of the DMTAP molecules in the lipid subphase

With addition of DMTAP lipid molecules to the subphase the surface decreased, indicating adsorption of the lipid molecules at the interface. We measured an about 5 -fold decrease in surface pressure from $27 \mathrm{mN} / \mathrm{m}$ to $5 \mathrm{mN} / \mathrm{m}$ with change in concentration of the lipid biomolecules from 0 to $100 \mathrm{nM}$ indicates effective adsorption of the lipid molecules at the interface. This reveals that the adsorption kinetics is instantaneous and the lipid biomolecules assemble as shown in Fig. 2. The lipid molecules are amphiphilic in nature and thus the hydrophobic part of DMTAP will try to go in organic phase (Chl), whereas hydrophilic part will try to be in bulk phase (water). All the experiments are repeated five times for good statistics of the surface adsorption behavior and the average is plotted in Fig. 2.

The AFM studies were performed at two different concentrations of the lipid molecules in the chloroform subphase, $7 \mathrm{nM}$ and $25 \mathrm{nM}$ corresponding to surface pressure of $\sim 24 \mathrm{mN} / \mathrm{m}$ and $19 \mathrm{mN} / \mathrm{m}$, respectively. The data shown is for $25 \mathrm{nM}$ lipid only. The nanoparticle 
assembly experiments were performed at high concentration of $25 \mathrm{nM}$ lipid in the Chl-subphase. This was chosen to ensure high density lipid bio membrane at the W/Chl interface, to facilitate effective adsorption of Au NPs. Au NPs are adsorbed at the headgroup of lipid due to electrostatic attraction between negatively charge Au NPs and positively charged lipid headgroup.

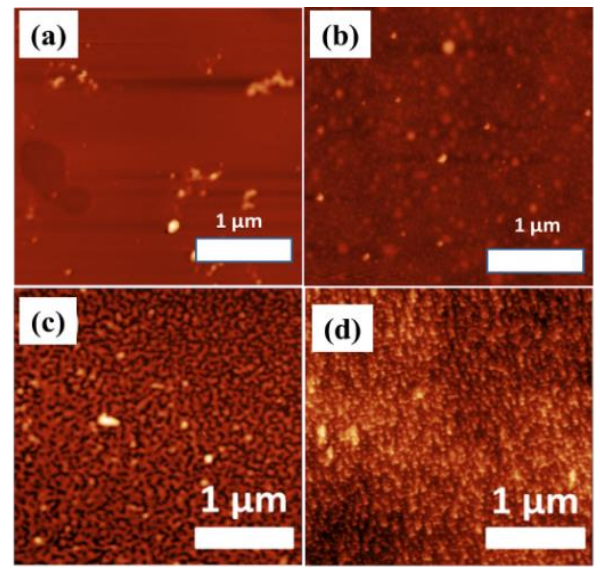

Fig. 3-AFM image of (a) bare substrate, (b) charged substrate, (c) DMTAP at $25 \mathrm{nM}$ and (d) Au NPs/lipid complex

The surface morphology data is shown in Fig. 3. Largely there are no surface features for the bare substrate. Few aggregates in the image (Fig. 3a) is due to presence of unavoidable dust particles. In Fig. 3b, we see some spherical features due to the presence of the charged polymer. However, for substrate with lipid membrane reveals large structures with formation of dense film as shown in Fig. 3c. The difference in the surface features for bare and charged substrate vs the substrate with lipid membrane, combined with the surface pressure data confirm the formation of a homogeneous lipid membrane at the interface.

To further investigate the electrostatic charge driven assembly behavior of the interface, oppositely charged Au NPs were added in the top phase of water as shown in Fig. 2a. Equilibration time of 1-2 h was given for Au NPs assembly at the interface via the elec-

\section{REFERENCES}

1. I.W. Hamley, Nanotechnol. Soft Mater. 42(15), 1692 (2003).

2. S. Chatterjee, M. Krikorian, D.G. Harry, MRS Online Proc. Lib. 1061, 908 (2007).

3. Ke. Gong, Si-Shen Feng, Mei Lin Go, Pei Hsing Soew, Colloid. Surf. A 207(1-3), 113 (2002).

4. A. Aroti, E. Leontidis, E. Maltseva, G. Brezesinski, J. Phys. Chem. B 108(39), 15238 (2004).

5. Ellen M. Adams, Clayton B. Casper, Heather C. Allen, J. Colloid Interface Sci. 478, 353 (2016).

6. A. Gurtovenko, M. Patra, M. Karttunen, I. Vattulainen, Biophysical J. 86(6), 3461 (2004). trostatic attraction between the negatively charged nanoparticle and the positively charged lipid membrane. As shown in Fig. 3c, there is an evident change in AFM structure with presence of high contrast spherical features corresponding to Au NPs, confirming the NP adsorption at the interface. Our results based on surface pressure and AFM studies indicates the formation of homogeneous charge lipid membrane at the W/Chl interface. The electrostatic attraction between the Au NPs and lipid membrane facilitates the Au NPs adsorption at the interface. The Au NPs_lipid hybrid monolayer prepared in our experimental studies shall serve as an ideal laboratory based system to study the interaction of the biomolecules with NPs in psychological environment, which is an important area of research for application in drug delivery.

\section{CONCLUSIONS}

In this work we report the self-assembly behavior of the charge lipid membrane at the W/Chl interface at different concentrations of the lipid molecules. We observed that the surface pressure decreases with an increase in the concentration of lipid molecules, which agrees with the theory of molecule adsorption on the interface. Ex-situ surface morphology studies of the lipid membrane transferred on solid substrates reveals the formation of homogeneous membrane. The charged lipid membranes were used to investigate the selfassembly behavior of the Au NPs at the liquid-liquid interface. Our results based on the surface pressure and the AFM studies indicates the formation of homogeneous charge lipid membrane at the water/chloroform interface. The electrostatic attraction between the Au NPs and lipid membrane facilitates the Au NPs adsorption at the interface.

\section{ACKNOWLEDGEMENTS}

AM acknowledges the Centre for research in nanotechnology and science (CRNTS, IITB). SS acknowledges the SERB-Ramanujan Fellowship. AM and SS thank IRCC IIT Bombay support for carrying out this research.

7. M. Cárdenas, T. Nylander, B. Jönsson, B. Lindman, J. Colloid Interface Sci. 286(1), 166 (2005).

8. A. Mogilevsky, Raz Jelinek, Langmuir 27(4), 1260 (2011).

9. Sunita Srivastava, D. Nykypanchuk, M. Fukuto, J.D. Halverson, A.V. Tkachenko, K.G. Yager, O. Gang, J. Am. Chem. Soc. 136, 23, 8323 (2014).

10. S. Srivastava, D. Nykypanchuk, M. Fukuto, O. Gang, ACS nano 8(10), 9857 (2014).

11. Melgardt M. De Villiers, et al., Adv. Drug Deliv. Rev. 63(9), 701 (2011).

12. J.Y. Park, R.C. Advincula, Nanocoatings and Ultra-Thin Films. Woodhead Publishing, 24 (2011). 


\title{
Самоорганізація наночастинок на межі поділу рідина-рідина
}

\author{
Akash Mishra $^{1}$, Sunita Srivastava ${ }^{2}$ \\ ${ }^{1}$ Centre for Research in Nanotechnology and Science, IIT Bombay, Powai, Mumbai, India \\ ${ }^{2}$ Department of Physics, IIT Bombay, Powai, Mumbai, India
}

\begin{abstract}
Ми представляємо експериментальні результати стосовно міжфразної організації гібриду наночастинки та біомолекулярної мембрани на межі поділу рідина-рідина. Динаміку адсорбції позитивно зарядженого ліпіду 1,2-диміристоїл-3-триметиламмоній-пропана (DMTAP) на межі поділу водахлороформ (W/Chl) досліджують in-situ за допомогою вимірювання міжфазного поверхневого натягу 3 використанням техніки Ленгмюра-Блоджета. Результат, який базуеться на вимірах поверхневого натягу для різних концентрацій молекул ліпіду DMTAP, виявляе, що поглинання молекул на межі W/Chl зростае із збільшенням концентрації DMTAP. Покриті цитратом негативно заряджені наночастинки золота (Au NPs) на позитивно зарядженій ліпідній мембрані були отримані за допомогою електростатичного притягання між Au NPs та ліпідною біомембраною. Морфологію поверхні 2D ліпідної мембрани та ліпідного комплексу Au NPs було охарактеризовано ex-situ за допомогою атомно-силової мікроскопії (AFM) шляхом перенесення ліпідного комплексу Au NPs на тверду підкладку з використанням техніки Ленгмюра-Блоджета. Ex-situ дані AFM та in-situ дані поверхневого натягу свідчать про те, що адсорбція ліпідних молекул покращуеться із збільшенням концентрації. Дані АFM виявляють утворення плівки Au NPs високої густини на межі поділу.
\end{abstract}

Ключові слова: Техніка Ленгмюра-Блоджета, Ліпідний моношар, Атомно-силова мікроскопія, DMTAP, Межа поділу рідина-рідина, UV-Vis спектроскопія, Зета-потенціал. 